\title{
Borehole Logging in Alpine Periglacial Talus Slopes (Valais, Swiss Alps)
}

\author{
Cristian Scapozza, ${ }^{1 *}$ Ludovic Baron $^{2}$ and Christophe Lambiel $^{3}$ \\ ${ }^{1}$ Institute of Earth Sciences (IST), University of Applied Sciences and Arts of Southern Switzerland (SUPSI), Canobbio, Switzerland \\ 2 Institute of Earth Sciences (ISTE), University of Lausanne, Lausanne, Switzerland \\ ${ }^{3}$ Institute of Earth Surface Dynamics (IDYST), University of Lausanne, Lausanne, Switzerland
}

\begin{abstract}
Geophysical measurements were carried out in six boreholes at three periglacial talus slopes in the Swiss Alps in order to determine the talus structure and the geological and permafrost stratigraphy. These are important elements of interpretation of the palaeoclimatic significance of Alpine talus slopes. This study combined three nuclear well logging methods. Natural radioactivity of rocks and ice-rich permafrost were determined by using natural gamma-ray logs through the lack of radioactivity of massive ice. Quantification of the ice content in frozen layers and the air content in unfrozen layers by variations in bulk density was provided by the application of gamma-gamma logs. Neutronthermal neutron logs were used to calculate the water content, linked with the porosity of the formation. Combination of the three logs allowed three-phase models (rock, ice and air/water) of the subsurface to be obtained. Results show that the air content decreases with depth because of the increasing in-situ stresses that cause compression of the rock debris and the existence of a fine matrix filling the voids. Calculation of the ice content variations shows that talus slopes are frequently partially saturated with ice or, at most, slightly supersaturated with ice. All three logs provide complementary information on the progressive infilling of the voids with depth and the occurrence of ice-rich layers. A similar trend in ice content and the apparent porosity was highlighted by the joint application of gamma-gamma and neutron-neutron logs, which provide a mirror image of these two parameters. Copyright (C) 2015 John Wiley \& Sons, Ltd.
\end{abstract}

KEY WORDS: borehole geophysics; nuclear well logging; porosity; ice content; talus slope; Swiss Alps

\section{INTRODUCTION} of Alpine periglacial terrains has mainly focused on rock glaciers (e.g. Barsch, 1996; Haeberli et al., 2006; Scapozza et al., 2014). Less interest has been shown for the study of Alpine periglacial talus slopes, which constitute one of the most common landforms in many mountain environments (e.g. Francou and Hétu, 1989; van Steijn et al., 2002). Recent studies have nevertheless shown that the analysis of the talus structure, and of the permafrost stratigraphy therein, may be a significant element of interpretation of the morphogenesis of an Alpine talus slope (e.g. Sass and Krautblatter, 2007; Scapozza et al., 2011a). Studies focusing, in particular, on periglacial talus slopes have often been

*Correspondence to: C. Scapozza, Institute of Earth Sciences (IST), (SUPSI), Campus Trevano, 6952 Canobbio, Switzerland. E-mail: cristian.scapozza@supsi.ch
Scientific research related to the morphology and structure University of Applied Sciences and Arts of Southern Switzerland

based mainly on surface geophysical prospecting (e.g. Otto and Sass, 2006; Lambiel and Pieracci, 2008; Scapozza et al., 2011b) and/or the thermal characterisation of the ground surface and permafrost temperatures in boreholes (e.g. Lütschg et al., 2004; Phillips et al., 2009). Little interest has, so far, been given to geophysical prospecting in boreholes (so-called well logging) carried out in mountain permafrost, the development of which has been restricted mostly to scientific research.

Borehole logging is a promising tool for investigating the vertical distribution of a physical parameter, such as natural radioactivity (gamma-ray), density (gamma-gamma) and hydrogen content (neutron-thermal neutron) (Vonder Mühll and Holub, 1992). A well log consists of a continuous record of a physical parameter along a borehole. According to the objective of the study and the characteristics of the borehole, several methods of well logging have been developed since 1927, as, for example, electrical, magnetic, sonic or nuclear logs (e.g. Dakhnov, 1959; Pirson, 1963; Guyod and Shane, 1969; Keys and MacCary, 1971). These methods are

Accepted 4 November 2014 
principally used for oil, gas and mineral prospecting. Several methods have been used since 1970 for prospecting geological resources in Arctic and subarctic regions, with, as a consequence, increased development of well logging methods adapted for studying the subsurface in permafrost terrain (e.g. Ferrians and Hobson, 1973; W. J. Scott et al., 1978; Osterkamp and Payne, 1981; Petersen et al., 1985). The occurrence of ice in the ground can change the physical properties of the rocks significantly, which has made it necessary to develop new interpretation procedures for well logging carried out in permafrost terrain (J. H. Scott et al., 1986).

A pioneering study was carried out in mountain permafrost by Barsch et al. (1979) in a $7 \mathrm{~m}$ borehole drilled in micaschists during June 1976 in the active Gruben rock glacier, in the Saas Valley (Valais Alps, Switzerland), by nuclear logging. Borehole 2/1987 was drilled a decade later in the Murtél-Corvatsch rock glacier (62 m deep, revealing a body of massive ice with an average ice content of around $95 \%$ at depths between 3 and $28 \mathrm{~m}$ ) and Borehole 1/1990 in the Pontresina-Schafberg rock glacier (67 $\mathrm{m}$ deep, with crystalline bedrock that was reached at a depth of approximately $16 \mathrm{~m}$ ). Both boreholes were situated in the Upper Engadin, and offered an opportunity to carry out an almost complete series of well logging, with the application of nuclear, electrical and sonic logs (Vonder Mühll and Holub, 1992; Vonder Mühll, 1996; Vonder Mühll et al., 2000). The use of well logging was encouraged more recently in the deep boreholes of the Permafrost And Climate in Europe (PACE) program (e.g. Harris et al., 2001), where it was carried out in the boreholes at Juvasshøe (Jotunheimen, Norway) and Murtèl-Corvatsch (Upper Engadin, Switzerland). Well logging in permafrost was carried out once more in the Upper Engadin, in boreholes drilled in the Muragl rock glacier (Boreholes 1-4/1999, with a depth of between $64 \mathrm{~m}$ for Borehole 2/1999 and $72 \mathrm{~m}$ for Borehole 3/1999 while the gneissic bedrock was reached at a depth of between approximately $32 \mathrm{~m}$ in Borehole 4/1999 and 49.5 $\mathrm{m}$ in Borehole 1/1999; Arenson, 2002; Arenson et al., 2002; Maurer et al., 2003; Musil et al., 2006; Springman et al., 2012).

Recent drilling projects in three periglacial talus slopes of the western Swiss Alps (Figure 1; see Scapozza et al., 2011a, 2011b; Scapozza, 2013) opened up the possibility of carrying out borehole geophysical measurements to study the stratigraphy and the permafrost structure of the landforms. The main objective of this study was to analyse the local talus structure of six boreholes drilled in three talus slopes and to study their stratigraphy. The study sites are composed of different lithologies, which may influence their grain size and thus their porosity, and show different morphological characteristics, as, for example, the existence or lack of creeping permafrost landforms. For this purpose, the aim of the study was achieved by combining three nuclear well logging methods: the natural gamma-ray log for measuring the natural radioactivity of the rocks; the gamma-gamma log for calculating the bulk density; and the neutron-thermal neutron log for quantifying the apparent porosity.

\section{INVESTIGATION SITES}

\section{Les Attelas Talus Slope}

The Les Attelas talus slope is located between 2620 and $2800 \mathrm{~m}$ asl on the west-facing flank of Mont Gelé $(3023 \mathrm{~m}$ asl), in the Verbier region (Figure 1b). This cone-shaped landform is composed of paragneiss (sericite-chlorite schists) and micaschists with amphibolites, and the average inclination of the talus is $29^{\circ}$ (Lambiel and Pieracci, 2008; Scapozza et al., 2011a, 2011b). Three boreholes were drilled along an upslope-downslope transect in September 2008. Borehole stratigraphies and temperatures, as well as electrical resistivity tomography profiles, showed that permafrost exists only in the lower part of the slope (Boreholes $1 / 2008$ and 2/2008). The ice content decreased in this sector, the permafrost became warmer and the active layer thickness increased towards the top of the slope (Scapozza et al., 2011a). Well logging was carried out on 20 July 2009 in Boreholes 1/2008 and 2/2008.

\section{Les Lapires Talus Slopes}

The Les Lapires talus slope constitutes a large debris accumulation, $500 \mathrm{~m}$ wide, located between 2370 and $2700 \mathrm{~m}$ asl on the northern side of the Pointe des Lapires (2973 m asl), in the Nendaz region (Figure 1c). The morphology of the slope is very heterogeneous, reflecting the multiple processes involved in its formation: rock falls and avalanches (which caused the concave form of the slope), permafrost creep, solifluction, debris flows and cryoturbation (Delaloye and Lambiel, 2005; Scapozza, 2013). The lithology of this site is the same as that of the Les Attelas talus slope. Investigations were focused on the western part of the slope. A $20 \mathrm{~m}$ deep borehole (Borehole 1/1998) was drilled in 1998 in the lower part of the slope, revealing the existence of permafrost at depths between 5 and $20 \mathrm{~m}$. Three new boreholes were drilled in October 2008 in an upslope-downslope transect. Borehole 11/2008 was $40 \mathrm{~m}$ deep and drilled in the lower part of the talus slope, close to Borehole 1/1998. Two additional boreholes were drilled in the middle (Borehole 12/2008) and the upper part of the slope (Borehole 13/2008). Permafrost occurred in Boreholes 11/2008 and $12 / 2008$, whereas it was absent from Borehole 13/2008 (Scapozza, 2013). Well logging was carried out in Boreholes $11 / 2008$ and 12/2008 on 30 September 2010 .

\section{Petit Mont Rouge Talus Slope}

Located on the eastern flank of the Petit Mont Rouge peak ( $2928 \mathrm{~m}$ asl), in the Arolla region, this small talus slope (about $200 \mathrm{~m}$ x 200m) is located between 2600 and $2700 \mathrm{~m}$ asl, underneath a $200 \mathrm{~m}$ high rock wall (Figure 1d). The average slope angle is $31^{\circ}$. The lithology is composed of metamorphic dolomites, locally alternating with limestones and marls. A lobate active protalus rampart, about $10 \mathrm{~m}$ thick with a steep (about $35^{\circ}$ ) front, occupies the base 

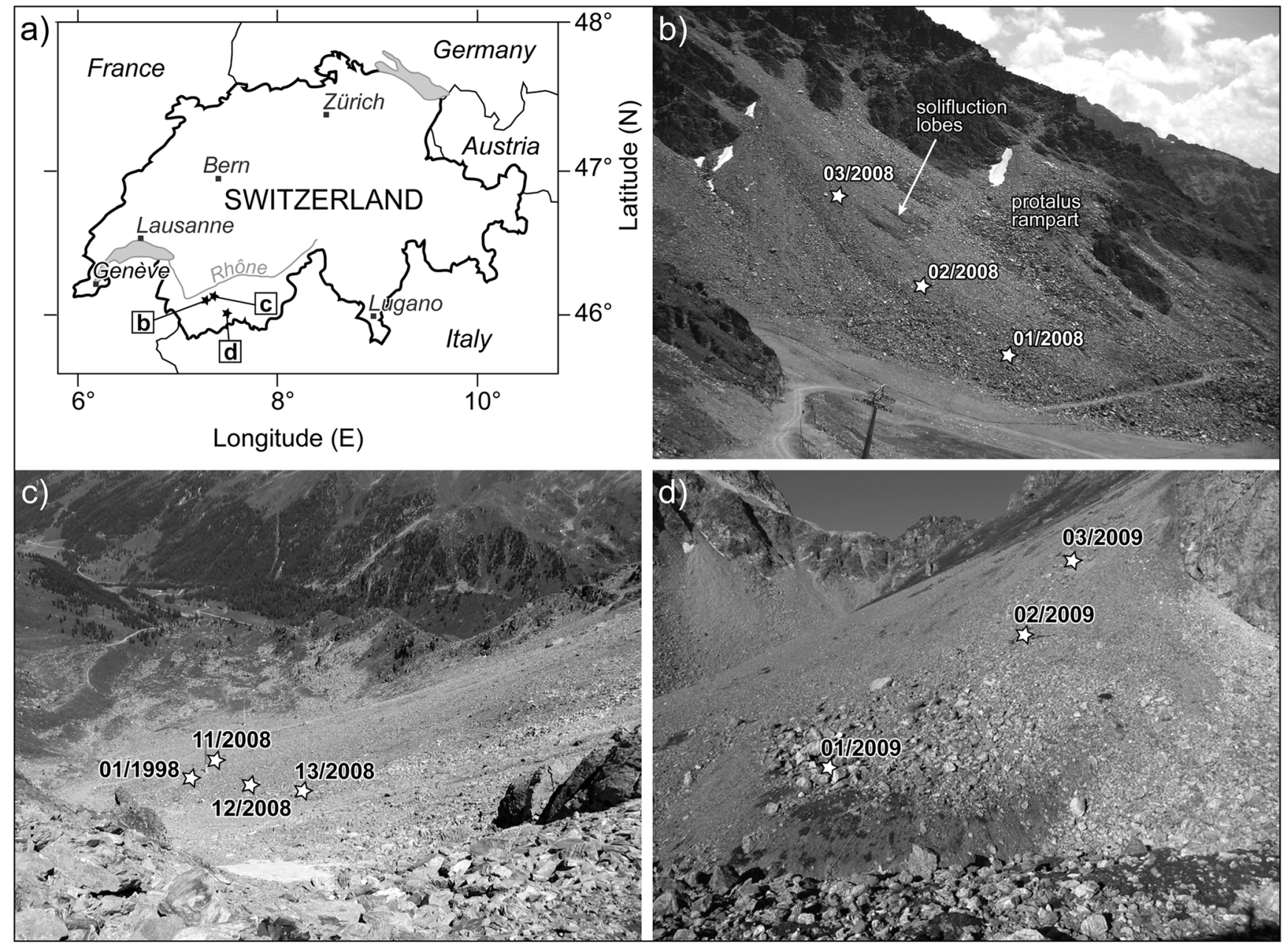

Figure 1 Geographical location and photographs of the studied talus slopes, with locatio ns of the drilled boreholes. (a) Location of boreholes in the Canton Wallis/Valais in Switzerland. (b) Les Attelas talus slope (Verbier area). (c) Les Lapires talus slopes (Nendaz area). (d) Petit Mont Rouge talus slope (Arolla area).

of the northern part of the slope and dominates a relict rock glacier (Lambiel and Pieracci, 2008; Scapozza et al., 2011a). Three boreholes were drilled during August 2009 in the protalus rampart (Borehole 1/2009) and the talus slope above it (Borehole 2/2009 in the lower part and Borehole $3 / 2009$ in the upper part of the talus). The geological structure and temperature data showed that permafrost occurred in Boreholes 1/2009 and 2/2009, whereas it was absent from Borehole 3/2009 (Scapozza et al., 2011a; Scapozza and Laigre, 2014). The active layer thickness increased from $4 \mathrm{~m}$ in Borehole 1/2009 to $9 \mathrm{~m}$ in Borehole 2/2009. A comparison between geological stratigraphy and temperature data showed that the permafrost was dry at temperatures below $0{ }^{\circ} \mathrm{C}$ without ice at depths between 18 and 22-23 $\mathrm{m}$ in Borehole 1/2009, and at depths between 15.5 and $20-25 \mathrm{~m}$ in Borehole 2/2009 (Scapozza, 2013). Well logging was carried out in Boreholes 1/2009 and 2/2009 on 1 October 2010.
Table 1 . Natural radioactivity of the main sedimentary rocks and other materials available in a permafrost terrain (after Hilchie, 1978, and Chapellier, 1987).

\begin{tabular}{lc}
\hline Material & Gamma-ray emission (API) \\
\hline Dolomite & $10-100$ \\
limestone & $10-110(220)$ \\
sandstone & $50-120(350)$ \\
silty sandstone & $80-300(350)$ \\
sand & $30-80$ \\
silty sand & $100-220(350)$ \\
clays & $80-320(500)$ \\
air & 0 \\
ice & 0 \\
\hline
\end{tabular}

${ }^{\mathrm{a}}$ The American Petroleum Institute (API) unit allows the concentration of radioactive elements of a material to be calculated. A total of 16.5 API units corresponds to $1 \mu \mathrm{g}$ of radium for $1000 \mathrm{~kg}$ of material. 


\section{MATERIAL AND METHODS}

\section{The Natural Gamma-Ray Log}

Natural radioactivity of the rocks can be measured from the borehole $\log$ due to the occurrence of uranium (mainly $\left.{ }^{238} \mathrm{U}\right)$, thorium $\left({ }^{232} \mathrm{Th}\right)$ or potassium $\left({ }^{40} \mathrm{~K}\right)$ isotopes. Higher natural radioactivity can generally be detected in acidic rocks (granite, pegmatite, sandstone and sand of granitical origin), mudstones and clays (Table 1). Borehole logging was performed in two distinct lithologies that offered a significant difference in natural gamma-ray emission: high in paragneiss/micaschist (i.e. crystalline rocks) for the Les Attelas and the Les Lapires talus slopes and low in limestone/marls (sedimentary rocks) for the Petit Mont Rouge talus slope.

The natural gamma-ray log may be used to estimate lithology. As the natural radioactivity of ice is zero, the occurrence of massive ice in a homogeneous lithology can be detected by its lack of radioactivity (J. H. Scott et al., 1986). Measured negative anomalies in such a log correspond to the existence of massive ice (Petersen et al., 1985). However, as air also has a natural radioactivity of zero, the natural gamma-ray log only allows the detection of the existence of permafrost that is supersaturated with ice (i.e. with a volume of ice higher than the volume of the voids). In this case, the lack of radioactivity due to the occurrence of ice is more significant than the radioactivity of the rock debris and the interstitial matrix.

The natural radioactivity was measured in this study by a scintillation counter, which gave a response in counts per second (CPS) of the entire formation investigated. The interpretation of the results is therefore qualitative. The volume penetrated during the emissions corresponds to a sphere centred on the detector from which 99 per cent of the detected gamma-rays originate. This volume does not have a fixed limit, and can vary between 20 and $90 \mathrm{~cm}$, as a function of the formation investigated, the instrument, the borehole diameter and the type of tube (Chapellier, 1987).

\section{The Gamma-Gamma Log}

\section{Technical Characteristics.}

The gamma-gamma log, also called a density log, is sensitive to the electron density of a formation, which mainly depends on its bulk density. The density of a formation depends on the density of the matrix, the porosity and the density of the imbibition fluid. The variations in density in permafrost with a homogeneous lithology are due to the air content and/or the ice content so that the gamma-gamma log measures the density of the matrix for zero free pore space. Ice-rich permafrost and massive ice can then be detected by their effect on density (W. J. Scott et al., 1978; J. H. Scott et al., 1986).

The method works by subjecting the formation to a beam of gamma-rays of a given energy $(0.1$ to $1 \mathrm{MeV})$ and the measurement of the gamma-rays diffused (in CPS). The penetration depth of the gamma-rays emitted is about $15 \mathrm{~cm}$ (Chapellier, 1987; Vonder Mühll and Holub, 1992). The higher the electron density, the more the energy of the beam will be attenuated. The occurrence of massive ice (low air content sections) corresponds to positive anomalies in a gamma-gamma log, which reflects an exponential response to bulk density, and which decreases as the measured CPS increases. Consequently, the gamma-gamma log is very sensitive to variations in bulk density for values lower than $2 \mathrm{~g} / \mathrm{cm}^{3}$ (Vonder Mühll and Holub, 1992). The conversion between CPS and bulk density is done by a calibration curve (Mari et al., 1999; Baron and Chapellier, 2000; Chapellier et al., 2000), which may be determined from known values of bulk density and borehole conditions.

\section{Calibration of the Gamma-Gamma Log.}

The calibration was based on values measured in situ in bedrock for the Les Attelas talus slope. The minimal intensity of the gamma-gamma log (1200 CPS) was indeed measured in the deeper part of Borehole 2/2008 and a mean value of $2.7 \mathrm{~g} / \mathrm{cm}^{3}$ was chosen for the micaschists and chlorite gneiss of the Mont Fort Nappe, on the basis of the literature (Chapellier, 1987). The calibration curve was calculated empirically from tests carried out in a PVC tube in the laboratory by the Institute of Geophysics at the University of Lausanne and the slope was derived as required (http://www-ig.unil.ch/cours/c_diaf.htm [5 September 2013]). Considering the empirical data measured on the Les Attelas talus slopes and the slope of the calibration curve from the laboratory calculation, the calibration curve obtained for this site (Figure 2a) was:

$$
\delta_{b}=-0.0008 * I_{G G}+3.66
$$

with: $\delta_{\mathrm{b}}=$ bulk density of the formation $\left[\mathrm{g} / \mathrm{cm}^{3}\right]$; and $\mathrm{I}_{\mathrm{GG}}=$ intensity of the gamma-gamma log [CPS].

As the Les Lapires talus slope has the same lithology as that of the Les Attelas talus slope (sericite-chlorite schists and micaschists), this calibration curve can also be applied for data measured at this site. There are no measurements of the intensity of the gamma-gamma log in bedrock for the Petit Mont Rouge talus slope. The lowest $\mathrm{I}_{\mathrm{GG}}$ value measured in situ (1320 CPS) was used as a reference value for dolomites and limestones of the Mont Dolin series. This value was measured where the geological stratigraphy of the boreholes revealed boulders larger than $1 \mathrm{~m}$. It was possible to consider a large boulder as a good approximation of the bedrock as the penetration depth was limited. A mean bulk density of $2.8 \mathrm{~g} / \mathrm{cm}^{3}$ was used on the basis of the literature (Chapellier, 1987). The calibration curve obtained for the Petit Mont Rouge talus slope is parallel with the calibration curve for the Les Attelas site as the characteristics of the boreholes (diameter, PVC tube) and the gamma-gamma log for the two sites were the same (Chapellier, 1987). The calibration curve obtained for the Petit Mont Rouge talus slope (Figure 2a) was:

$$
\delta_{b}=-0.0008 * I_{G G}+3.86
$$

On the basis of $\delta_{b}$, it is possible to determine the ice content $\Phi[\%]$ by Equation 3, considering a bulk density of $2.7 \mathrm{~g} / \mathrm{cm}^{3}$ 

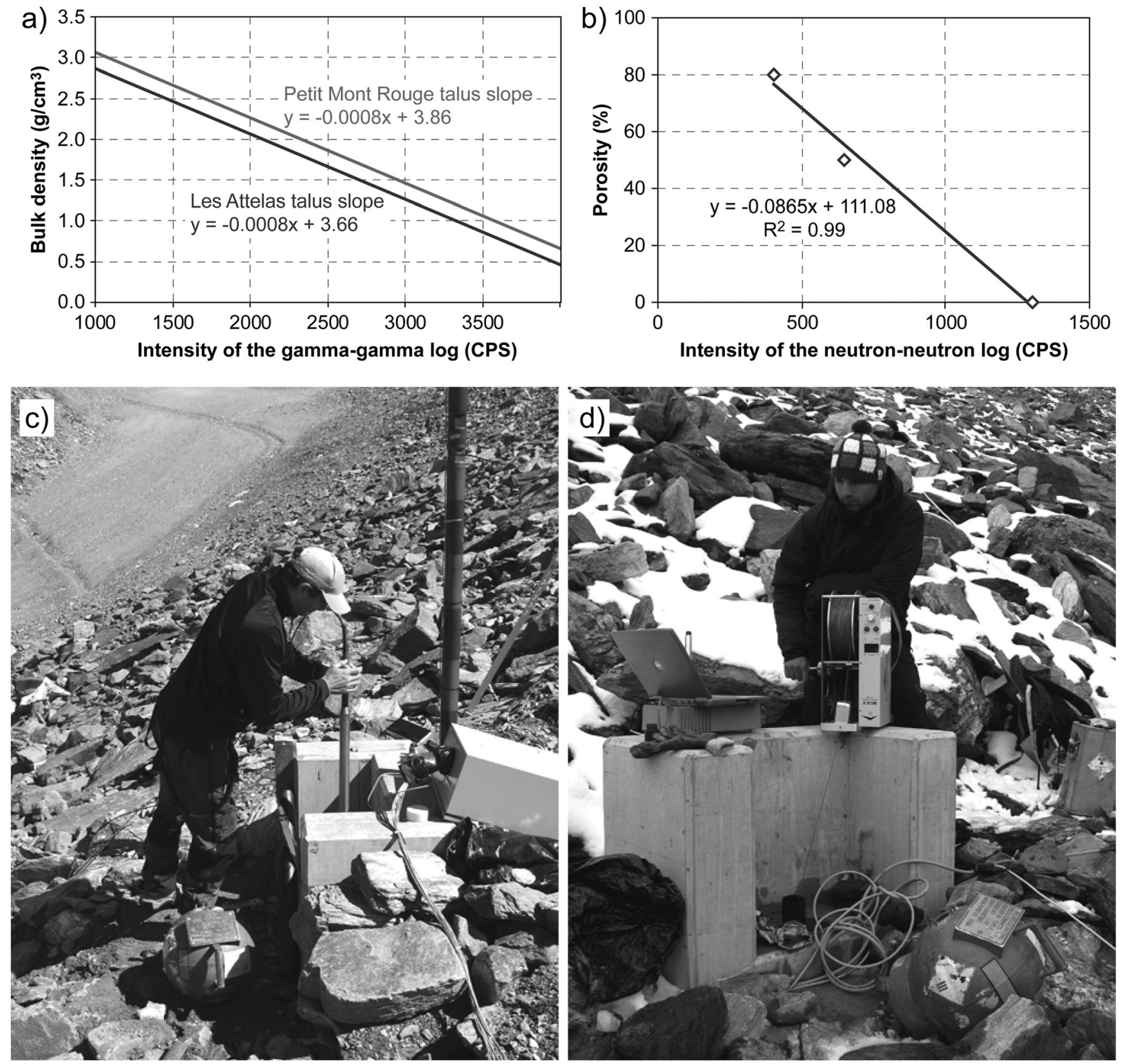

Figure 2 Well logging calibration and use in the field. (a) Calibration curves of the gamma-gamma log for the Les Attelas and the Petit Mont Rouge talus slopes. (b) Calibration of the neutron-neutron log for the Les Attelas talus slope. (c) Placement of the neutron-neutron sensor in Borehole 2/2008 on the Les Attelas talus slope (20 July 2009). In the foreground, the lead bowl screens the nuclear source of the neutron-neutron sensor. (d) Well logging in Borehole $12 /$ 2008 on the Les Lapires talus slope (30 September 2010), with the portable winch MGX-II and the digital data logger MATRIX (Denver (CO), USA) (below the laptop). The wooden case on the right can be seen with the lead screen of the nuclear source of the gamma-gamma sensor.

$\left(2.8 \mathrm{~g} / \mathrm{cm}^{3}\right.$ for the Petit Mont Rouge talus slopes) for the matrix $\left[\delta_{m}\right]$ and $0.9 \mathrm{~g} / \mathrm{cm}^{3}$ for ice $\left[\delta_{i}\right]($ J. H. Scott et al., 1986; Vonder Mühll and Holub, 1992):

$$
\Phi=\left(\delta_{m}-\delta_{b}\right) /\left(\delta_{m}-\delta_{i}\right) * 100
$$

In zones without ice, Equation 3 allows the air content to be estimated by considering a bulk density of air (practically) of zero (the bulk density of air is $0.0012 \mathrm{~g} / \mathrm{cm}^{3}$ at $20^{\circ} \mathrm{C}$ at sea level).

\section{The Neutron-Thermal Neutron Log}

Technical Characteristics.

This log, also called a hydrogen log, henceforth simply called a neutron-neutron log, is measured by a device 
containing a source of rapid neutrons and with a detector allowing the quantification of the thermalised neutron flux. The neutrons emitted penetrate rock to a depth of about $15 \mathrm{~cm}$ (Vonder Mühll and Holub, 1992). The neutron flux is directly affected by the content of hydrogen atoms, which is related to the saturation in water or ice (W. J. Scott et al., 1978; J. H. Scott et al., 1986). The number of neutrons that reach the detector increases exponentially when the hydrogen content decreases, and vice versa. The existence of ice or water in the neutron-neutron log then corresponds to negative anomalies, which is contrary to the result in the gamma-gamma log. The joint application of gamma-gamma and neutron-neutron logs allows the stratigraphy of ice-rich layers to be determined on the basis of positive anomalies in the gamma-gamma log, which are in correspondence with negative anomalies in the neutron-neutron log.

The porosity may then be deduced based on an assumption of a saturated formation (Chapellier, 1987; Vonder Mühll and Holub, 1992) or further evidence about the air content for a partially saturated matrix. The response obtained from the logging is not only related to hydrogen atoms of liquid or solid water, but also to the hydrogen trapped in the crystalline network of the rocks. The derived porosity is then defined as an apparent porosity or neutron porosity. By definition, the porosity is 100 per cent in pure water and zero in a limestone of null porosity, where no hydrogen is present (Chapellier, 1987). The neutron-neutron $\log$ is very sensitive, in particular to small variations in water or ice content below 30 per cent (Vonder Mühll and Holub, 1992).

\section{Calibration of the Neutron-Thermal Neutron Log.}

An empirical calibration was carried out for the Les Attelas talus slope on the basis of porosity values estimated directly in situ in the boreholes. For a very low porosity (i.e. no free pore spaces), a value of 1300 CPS was obtained, corresponding to the maximal value measured in the frozen body of the Boreholes $1 / 2008$ and 2/2008. A value of 650 CPS was obtained for a porosity of 50 per cent, corresponding to the mean value measured at a depth of $11-12 \mathrm{~m}$ in Borehole 1/2008, where an ice content of about 50 per cent was determined by the quantification of ice and rock volumes on the basis of the analysis of materials expelled at the moment of drilling (see Scapozza, 2013). Finally, a value of 400 CPS was obtained for a porosity of 80 per cent on the basis of data described in the literature by Vonder Mühll and Holub (1992). The calibration curve for the neutron-neutron log (Figure 2b) is:

$$
\Phi_{a}=-0.0865 * I_{N N}+111.08
$$

with: $\Phi_{\mathrm{a}}=$ apparent porosity $[\%]$; and $\mathrm{I}_{\mathrm{NN}}=$ intensity of the neutron-neutron log [CPS].

As for the gamma-gamma log, according to the same lithology for both sites, the calibration curve established for the Les Attelas talus slope can also be applied to the Les Lapires site. For the Petit Mont Rouge talus slope, on the contrary, it was not possible to make a calibration of the neutron-neutron log because no information about the ice content in the saturated zones was available for this site.

\section{Data Acquisition}

The well logging method that can be used depends on the characteristics of the borehole and its environment. Since it is necessary to flood the borehole with water when using electrical or sonic logs and, in some cases, the neutronneutron log (Vonder Mühll and Holub, 1992), and this was not possible, for technical and logistic reasons (water transport on the site, high permeability of the ground, boreholes already equipped with PVC tubes), only nuclear logs were carried out in the three talus slopes studied. It can then be assumed that the subsurface was never completely saturated due to the high permeability of the unfrozen ground and the likelihood of air being trapped in the permafrost (Arenson and Springman, 2005). This implies, for the neutron-neutron log, that it is impossible to determine the saturation (no response is provided for a $\log$ in a saturated formation), but only an apparent porosity influenced by the air content of the PVC tube (Chapellier, 1987).

Data acquisition was made with a portable well logging system by the Mount Sopris Instrument Company Inc. (Denver (CO), USA) (Figure 2c, d). The gamma-gamma and neutron-neutron logs are powered by a ${ }^{137} \mathrm{Cs}$ source (with an activity of $0.185 \mathrm{GBq}$ ), with a combination of americiumberyllium $\left({ }^{241} \mathrm{Am}-{ }^{9} \mathrm{Be}\right)$ of $37 \mathrm{GBq}$, respectively. The device for the natural gamma-ray log and the receiver of the gammagamma log are composed of a scintillation counter allowing the measurement of gamma-rays. The receiver of the neutron-neutron log functions with helium-3 $\left({ }^{3} \mathrm{He}\right)$.

All of the well loggings were carried out 1 to 2 years after the drilling in the PVC tube that had been inserted into the boreholes to limit any effects of variations in the borehole diameter. This gap in time allowed the contact between the ground and the PVC tube to be improved, either by settlement of the solid matrix, or water freezing in voids around the tube, and the permafrost temperature to equilibrate after the thermal perturbations of the ground related to the drilling operations. Carrying out well logging in PVC tubes offers two main advantages: on the one hand, these tubes do not influence the nuclear properties of the ground; and on the other hand, it allows a hole of constant diameter to be maintained, which is essential for correct calibration of the gammagamma and neutron-neutron logs (Chapellier, 1987).

\section{RESULTS}

\section{Les Attelas Talus Slope}

\section{Data.}

The natural gamma-ray logs from the two boreholes indicate several distinct anomalies. Measurements logged in Borehole 1/2008 show generally an increase in the 

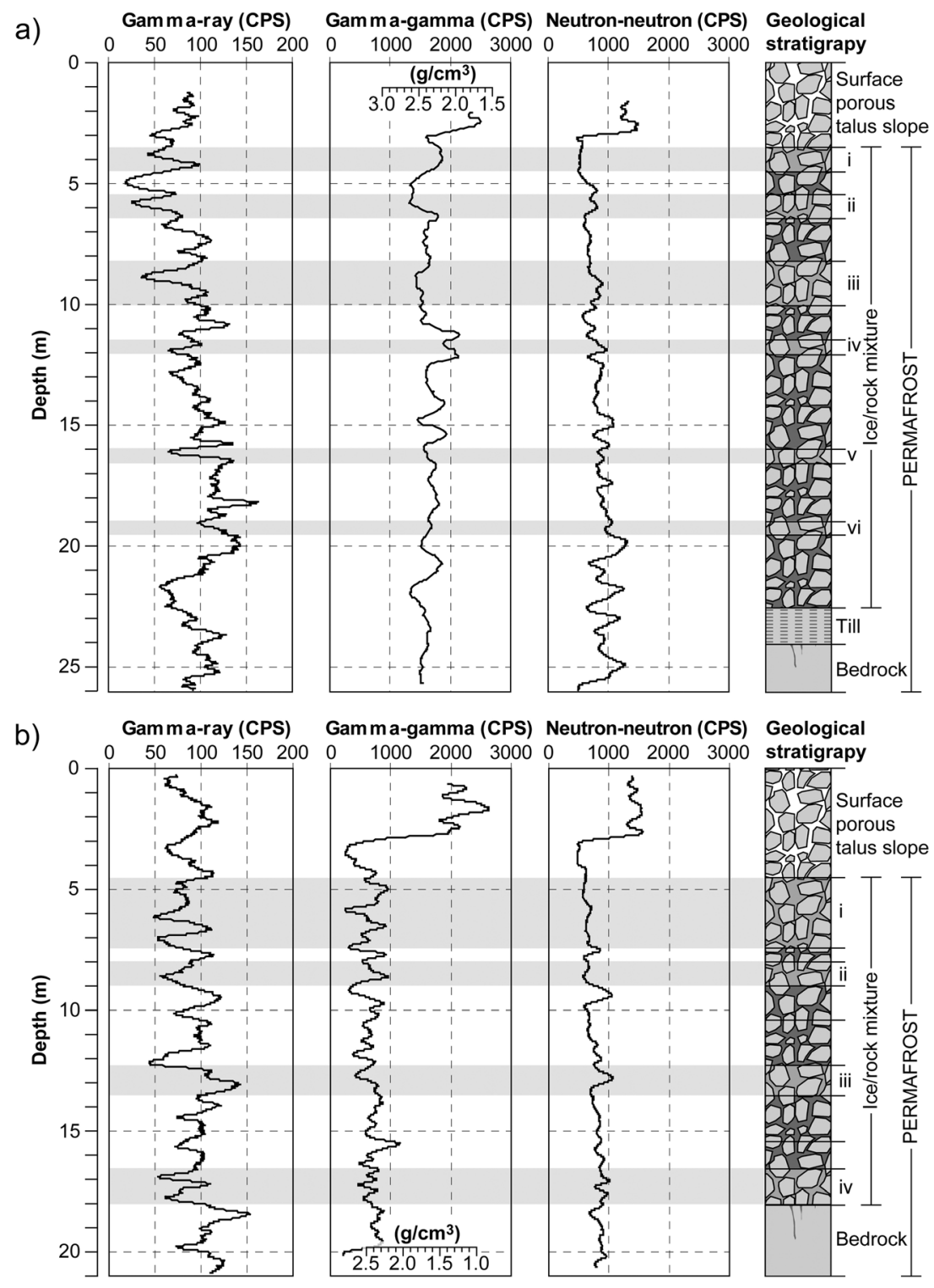

Figure 3 Results of well logging carried out on 20 July 2009 on the Les Attelas talus slope. Grey-shaded sections indicate ice-rich layers (i-vi) according to the geological stratigraphy, which was determined from visual inspection using a camera and material expulsion (for details, see Scapozza, 2013). (a) Borehole 1/2008. (b) Borehole 2/2008.

intensity of gamma-rays between depths of 2 and $20 \mathrm{~m}$ (Figure 3a). The natural gamma-ray log measured in Borehole 2/2008, which shows greater peaks and troughs with anomalies of several tens of CPS (Figure 3b), displays also a similar but less visible trend, although the larger fluctuation than in Borehole $1 / 2008$ hides the trend. The transition into the bedrock in Borehole 2/2008 is characterised by the most significant positive anomaly (150 CPS).

The transition between the active layer and the permafrost body is characterised in the gamma-gamma log from both boreholes by a notable decrease in intensity. This behaviour is clearly seen in Borehole 2/2008, where a decrease between 3500 and 2000 CPS can be observed over a few metres.
As for the gamma-gamma log, the transition between the active layer and the permafrost body is characterised in the neutron-neutron log by a large decrease in intensity of the log (Figure 3). Weak changes in amplitude can be seen in the data obtained from the neutron-neutron $\log$ within the permafrost body, which may be due to the larger investigation volume. Calibration of the apparent porosity is necessary to be able to interpret the anomalies with some consistency (Figure 4).

\section{Interpretation.}

Increase in the intensity of the gamma-rays may indicate a decrease in air content with depth, related to a more wellgraded matrix. This log indicates that the talus slope is probably not supersaturated with ice; therefore, it is very difficult 


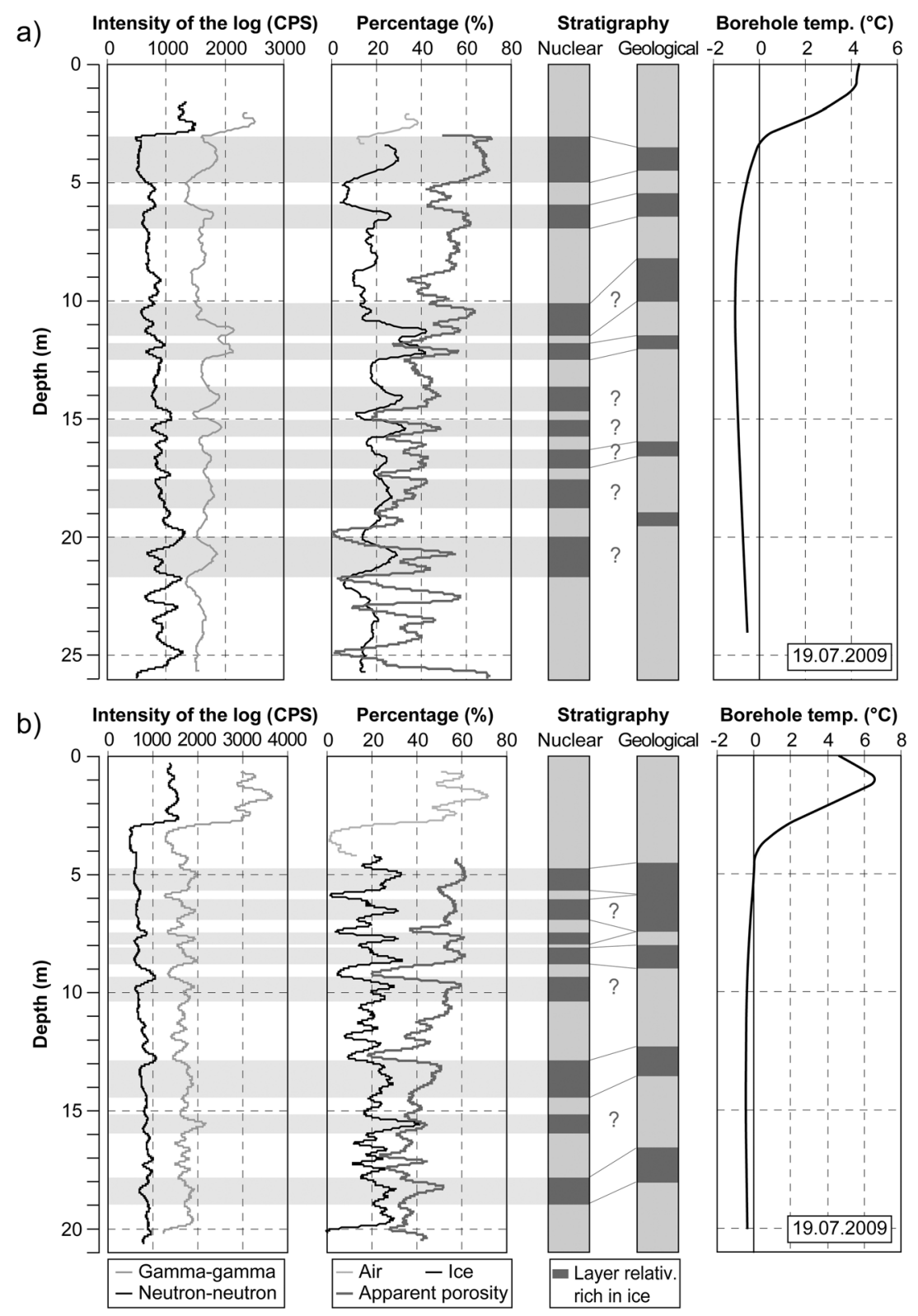

Figure 4 Quantification of ice content, porosity and nuclear stratigraphy of well logging at Les Attelas. Grey-shaded sections indicate ice-rich layers according to the nuclear stratigraphy. Geological stratigraphy was determined during drilling and by the use of a borehole camera (for details, see Scapozza et al., 2011 a).

(a) Borehole 1/2008. (b) Borehole 2/2008.

to detect ice-rich layers. This may be the case for ice-rich layers, which were determined in situ by combining observations directly during drilling, and just after, by using a borehole camera (Scapozza et al., 2011a), ii, iii and $\mathrm{v}$ in Borehole 1/2008 (Figure 3a), and i, ii and iv in Borehole 2/2008 (Figure 3b).

As shown in the air content profile (Figure 4b), high values of gamma-gamma intensity in the first part of the active layer are related to high air content, which is typical for the surface of a talus slope (loose rock debris). High bulk density and very low air content are derived for the base of the active layer in Borehole 2/2008 (Figure 4b): it is probable that this part is filled by fines that cannot be washed to lower depths because of the existence of the permafrost table. Variations in intensity for the gamma-gamma $\log$ are weaker in the deeper parts of the two boreholes (decrease in air content), and indicate that the ground is compressed by the increasing stresses with depth and further the soil matrix has become more well-graded. Interpretation in terms of ice content is particularly interesting, with the existence of several layers with an ice content higher than 20 per cent, with peaks reaching 40 per cent. The talus slope is partially saturated with ice at the location of Boreholes $1 / 2008$ and $2 / 2008$, with an ice content that is always lower 
than the apparent porosity. Negative anomalies with intensity lower than 1500 CPS (bulk density higher than $2.5 \mathrm{~g}$ / $\mathrm{cm}^{3}$ ) correspond to the occurrence of large boulders in both boreholes, which cause an increase in bulk density related to a decrease in ice content.

Apparent porosities calculated using the neutron-neutron $\log$ lead to the observation that the free pore space of ground within the talus slope decreases with depth in both boreholes. Large porosity variations are deduced below a depth of $22.0 \mathrm{~m}$ in Borehole 1/2008 (Figure 4a). This may indicate the existence of coarse talus slope debris, lodgement till with a well-graded fine matrix and an upper horizon of bedrock. The bedrock was probably fractured, as shown in the geological stratigraphy of this borehole, determined from visual inspection using a borehole camera and material expulsion (Scapozza et al., 2011a). The significant change in the stratigraphic structure of this part of the talus slope provokes large variations in ice content and apparent porosities. Considering that these two parameters were determined from two different logs, where the apparent porosity is lower than the ice content, it is probable that there is a large uncertainty in the measured parameter.

The calibration of the gamma-gamma and neutronneutron logs permits the visualisation of changes in ice content in the talus slope. The joint interpretation of both logs allows the occurrence of ice-rich layers to be determined. This approach is very robust, because the two logs give mirror images, both in variations in intensity and variations in ice content vs. the apparent porosity. It is therefore possible to determine a nuclear stratigraphy of relatively ice-rich layers (ice content higher than 20\%) for both boreholes (Figure 4). This nuclear stratigraphy gives more accurate information than geological stratigraphy. Some ice-rich layers deduced from the geological stratigraphy indeed correspond to several layers of the nuclear stratigraphy. In other cases, it is not possible to establish any correspondence between the two different stratigraphies. These differences are probably due to the difficulties of visual interpretation of icerich layers using a borehole camera, which is manually controlled (whereas well logging is automatically controlled by a winch) and limited only to the borehole walls.

\section{Les Lapires Talus Slope}

Data.

The records of the natural gamma-ray log reveal notable differences for both boreholes. Borehole 11/2008 shows variations of several tens of CPS (Figure 5a), implying a very heterogeneous stratigraphy, whereas the data from Borehole $12 / 2008$ are more linear, with a gradual increase in CPS with depth, implying that the formation is much more homogeneous (Figure 5b). Despite this significant difference between the natural gamma-ray logs, the geological stratigraphy is quite similar for both boreholes.

The transition between the active layer and the permafrost body is characterised in the gamma-gamma log for both boreholes by a large decrease in intensity of the log.
An increase in intensity at the permafrost base is visible only in Borehole 12/2008, showing the transition into a more porous layer. The gamma-gamma log for Borehole $11 / 2008$ shows a large decrease (from 2700 to 1300 CPS).

The transition between the active layer and the permafrost body in the neutron-neutron log is marked by a strong decrease in intensity of the log. A weak increase occurred below the permafrost base.

\section{Interpretation.}

Natural gamma-ray anomalies measured in Borehole $11 / 2008$ are weaker in the permafrost body (where they are related to small variations in ice content) than below the permafrost base. As shown in the geological log of this borehole, determined from the visual inspection using a camera and material expulsion (Scapozza et al., 2011a), the air content is very variable because of a probable stratification of the till deposits. The increase in intensity of the natural gamma-ray log below a depth of $10 \mathrm{~m}$ in Borehole $12 / 2008$ indicates a decrease in free pore space related to the increase in interstitial matrix with depth (Figure 5b).

The decrease in intensity determined from the gammagamma log in the transition between the active layer and the permafrost body at about $4 \mathrm{~m}$ depth indicates a transition between a porous surface layer and a layer that is partially saturated with ice (20-40\%), except for a supersaturated ice layer located at a depth of $15 \mathrm{~m}$ in Borehole 11/2008 (Figure 6a). The significant decrease in CPS from the gamma-gamma log at $19 \mathrm{~m}$ depth in Borehole 11/2008 is probably related to the existence of a layer composed of silty sands, as shown in the geological stratigraphy of this borehole (Figure 5a). This massive layer has the effect of increasing the bulk density, showing that air content is very low here. Significant variations in intensity for the gammagamma log between depths of 24 and $34 \mathrm{~m}$ show that this well-drained layer is located a few metres below the permafrost base (Figure 6a) and is also typified by large air voids around the boulders. Similar characteristics can also be identified, but to a lesser extent, in Borehole 12/2008 between depths of 20 and $26 \mathrm{~m}$ (Figure 6b).

Low air content may be derived in the permafrost body, from the neutron-neutron log for Borehole 11/2008, between depths of 10 and $19 \mathrm{~m}$, showing an increase in ice content (Figure 6a). This is less obvious in Borehole 12/2008, in which the apparent porosity decreases slowly as a function of depth, whereas ice content fluctuates between 30 and 50 per cent (Figure 6b). The gradual increase in data obtained from the neutron-neutron log below the permafrost base confirms the existence of a well-drained layer of boulders between depths of 24 and $34 \mathrm{~m}$ in Borehole 11/2008 and 20 and $26 \mathrm{~m}$ in Borehole 12/2008, as shown by the gamma-gamma log.

The nuclear stratigraphy for Borehole 11/2008 shows an increase in ice content until a depth of $10 \mathrm{~m}$, where it is about 40 per cent. A single layer can be identified that is supersaturated with ice, corresponding to the ice-rich layer determined in the borehole stratigraphy between depths of 13.5 and $14.5 \mathrm{~m}$ (Figure 6a). Determination of the depth of 
a)
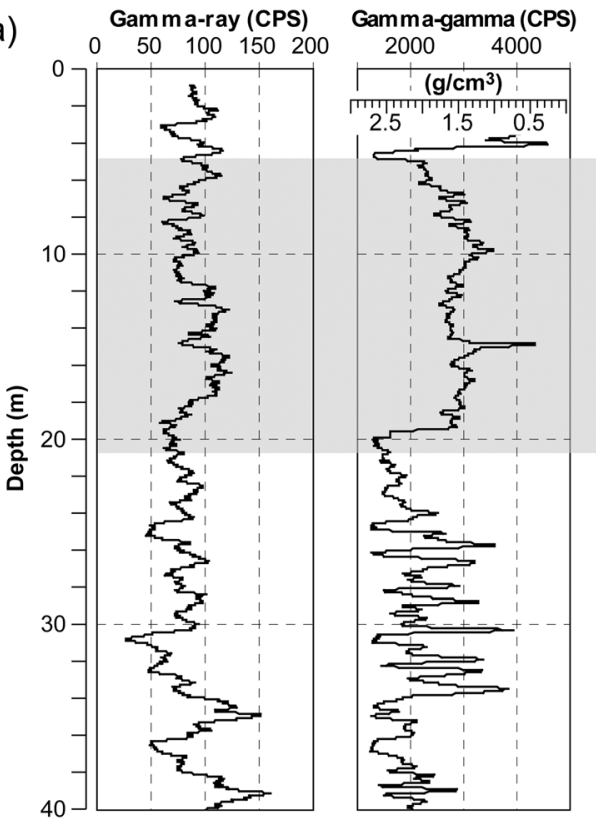

Neutron-neutron (CPS) Geological

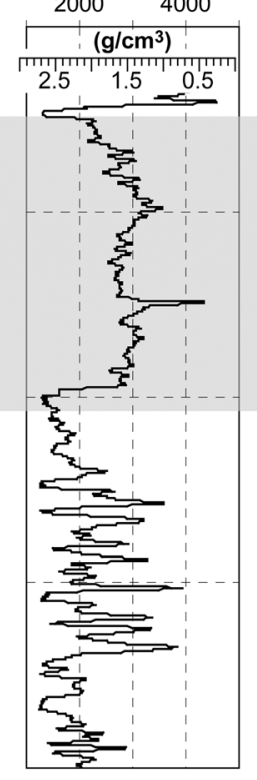

0 2004006008001000

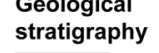

b) Gamma-ray (CPS)
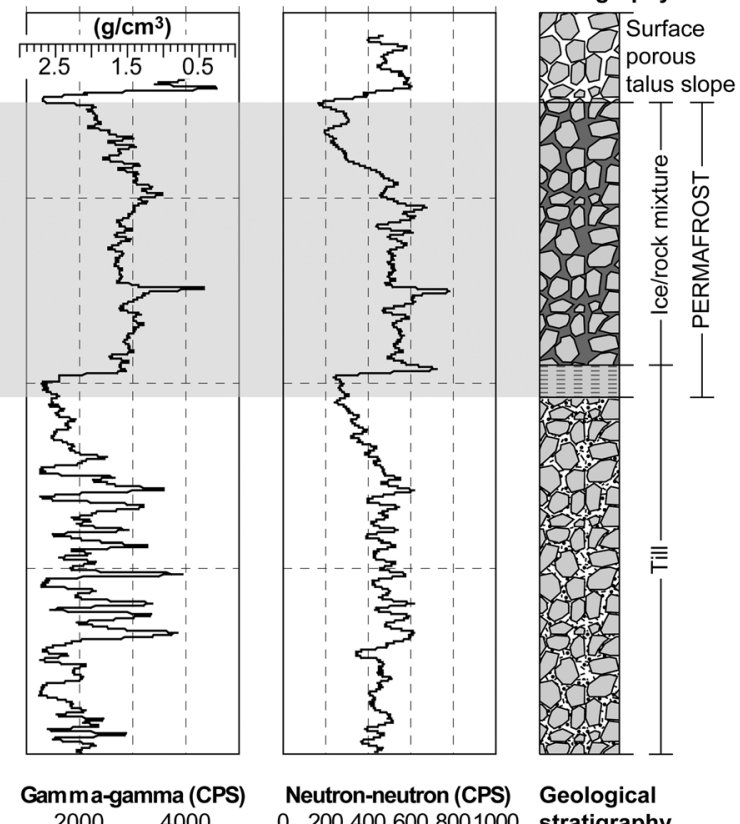

b)
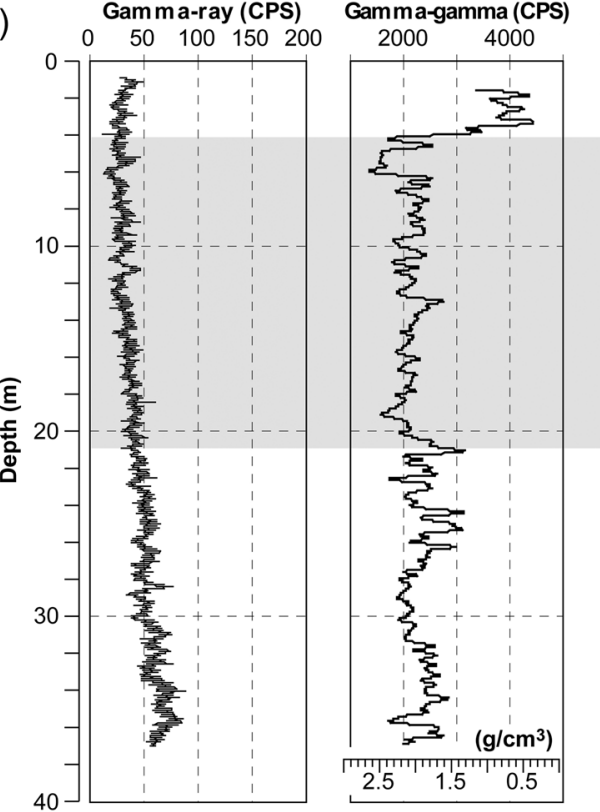

Neutron-neutron (CPS)

Geological 2004006008001000 stratigraphy

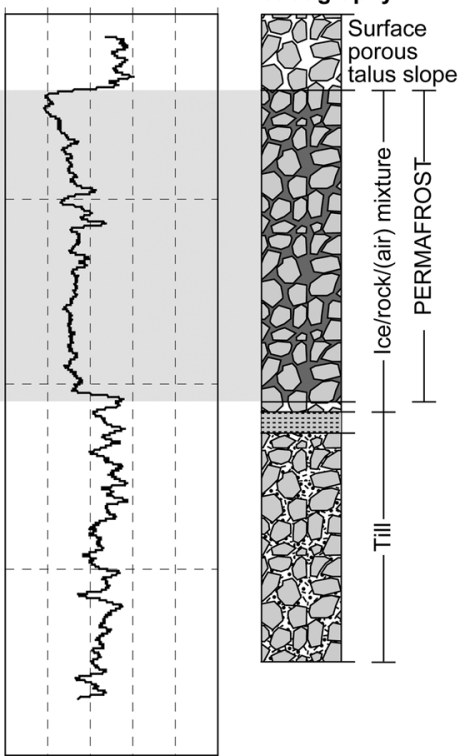

Figure 5 Results of well logging carried out on 30 September 2010 on the Les Lapires talus slope. Grey-shaded sections indicate the occurrence of ice in the geological stratigraphy, which was determined from visual inspection using a camera and material expulsion (for details, see Scapozza, 2013). (a) Borehole 11/ 2008. (b) Borehole 12/2008.

the permafrost base is not consistent when interpreting the well logs and the temperature data. This difference is probably due to the occurrence of a layer composed of silty sands and without ice, which induce considerable variations in intensity of the gamma-gamma and neutron-neutron logs.

The stratigraphy derived from Borehole 12/2008 does not indicate large variations in ice content. The nuclear stratigraphy, on the other hand, allows the image of the talus slope structure to be refined (Figure 6b): it shows the existence of five relatively ice-rich layers, with an ice content higher than 40 per cent (and with peaks reaching 60\%, which must be interpreted with caution). The ice content in this borehole seems to decrease with depth. As the apparent porosity also decreases, this can be explained by an increase in coarsergrained rock debris (corresponding to a decrease in voids) rather than a real decrease in ice content. As the talus slope is not supersaturated with ice, in general, variations in bulk density (intensity of the gamma-gamma $\log$ ) and the apparent porosity (intensity of the neutron-neutron $\log$ ) are subject to variations in air content. 

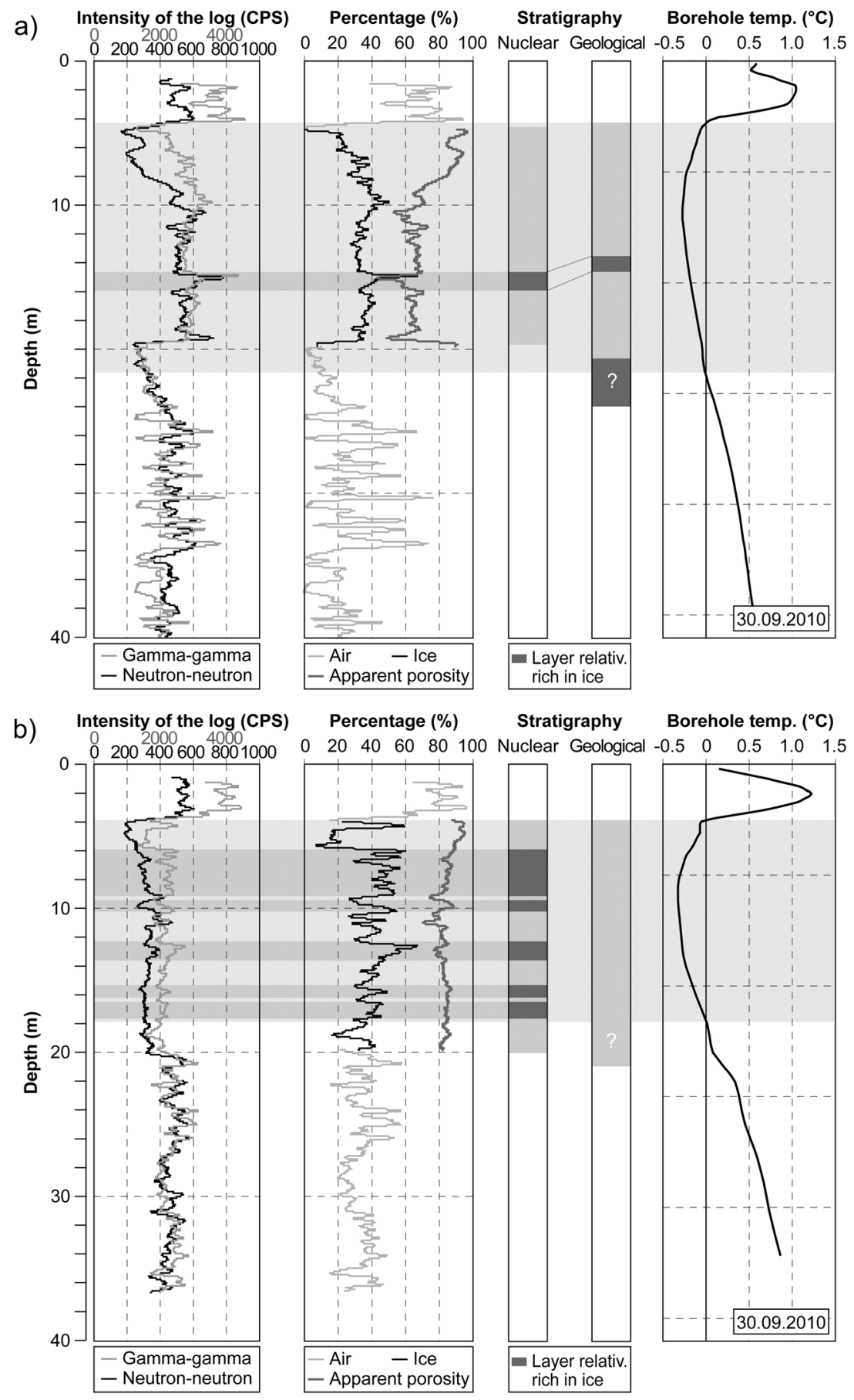

Figure 6 Quantification of ice content, porosity and nuclear stratigraphy of well logging carried out at Les Lapires. Dark grey-shaded sections indicate ice-rich layers according to the nuclear stratigraphy, whereas light grey-shaded sections indicate a frozen ground according to borehole temperature. Geological stratigraphy was determined during drilling and by the use of a borehole camera (for details, see Scapozza, 2013). (a) Borehole 11/2008. (b) Borehole 12/2008.

\section{Petit Mont Rouge Talus Slope}

Data.

The natural gamma-ray intensity is weak in both boreholes, as dolomites and marls do not contain radioactive minerals, and rarely exceeds 50 CPS. Variations of the order of tens of
CPS exist in both logs despite this point (Figure 7). The intensity of the gamma-rays fluctuates in Borehole 1/2009 until a depth of $10 \mathrm{~m}$, showing large variations in air content (Figure 7a). Values are more stable and between 20 and 30 CPS between depths of 12 and $22 \mathrm{~m}$. The gamma-ray intensity increases gradually in the active layer in Borehole 2/2009 

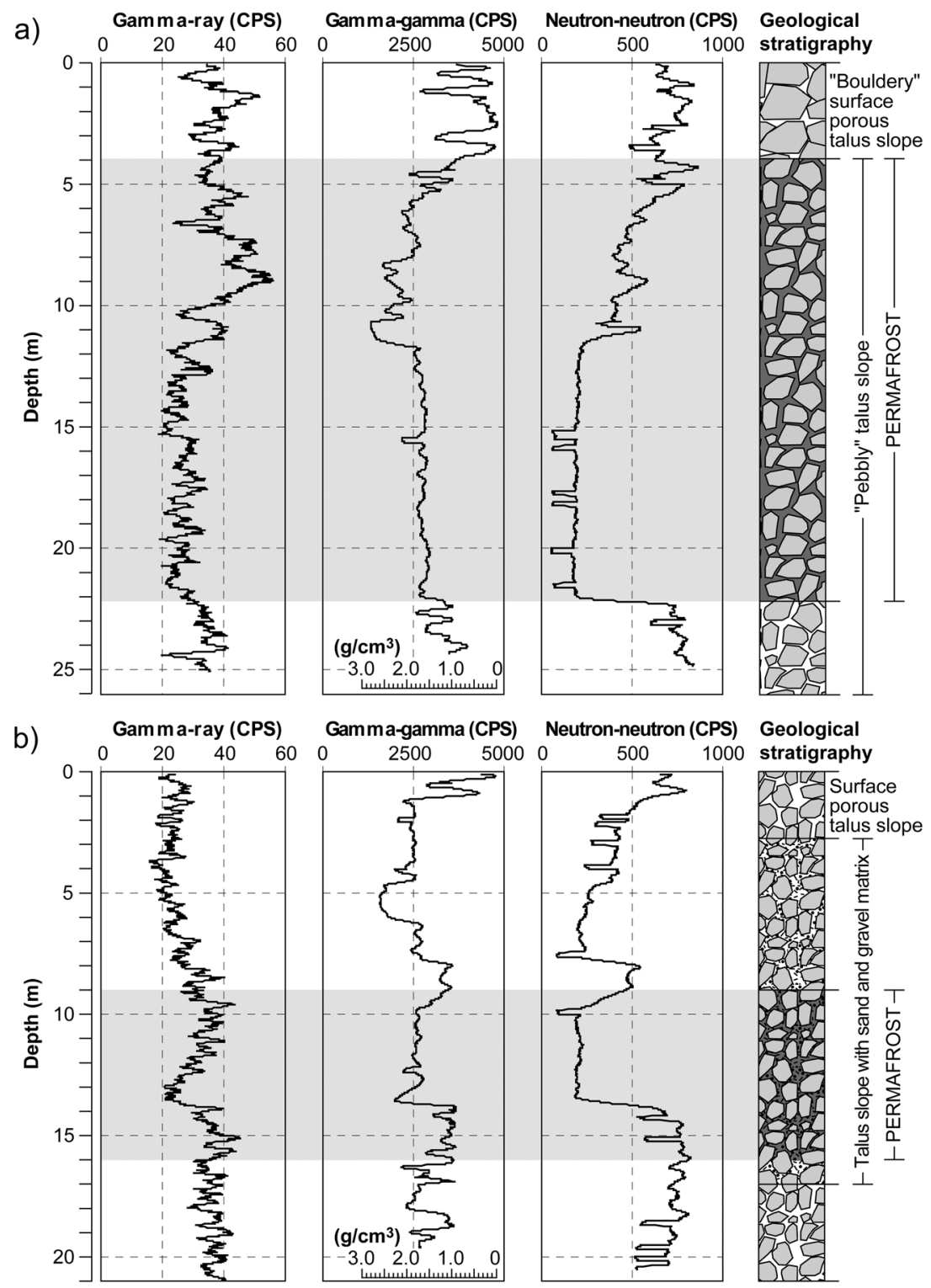

Figure 7 Results of well logging carried out on 1 October 2010 on the Petit Mont Rouge talus slope. Grey-shaded sections indicate the occurrence of ice in the geological stratigraphy, which was determined from visual inspection using a camera and material expulsion (for details, see Scapozza, 2013). (a) Borehole 1/ 2009. (b) Borehole $2 / 2009$.

(Figure 7b) and a negative trend of 20 CPS occurred between depths of 10 and $13.5 \mathrm{~m}$, which is then reversed up to $15 \mathrm{~m}$.

The loose rock debris surface layer of the talus slope is characterised in the gamma-gamma log in both boreholes by intensities of the log higher than 2500 CPS. The intensity of the gamma-gamma log decreases gradually in Borehole $1 / 2009$ until a depth of $11 \mathrm{~m}$, showing an increase in density of the talus slope linked to the progressive filling of the subsurface. The intensity of the log increases and fluctuates more below the permafrost base, showing the occurrence of a layer with increasing free pore space. This is not surprising. Circulating air below the permafrost base was also reported, for example, for the Muragl active rock glacier, in the Upper Engadin (Arenson et al., 2002).
The transition between the active layer and the permafrost body is not as clearly visible in the neutron-neutron $\log$ as was the case at Les Lapires (Figure 6). This log is characterised by a decrease in the intensity of the log readings from 800 to 400 CPS between the surface and a depth of $11 \mathrm{~m}$ in Borehole 1/2009 and a stable intensity of 200 CPS between depths of 11.1 and $22.2 \mathrm{~m}$. The permafrost base is characterised by a large increase in intensity, from 200 to $730 \mathrm{CPS}$, showing that this sector is very porous. A similar trend is observed for the neutron-neutron log from Borehole 2/2009, with an intensity of about 200 CPS, the same value recorded in the protalus rampart between depths of 12 and $22 \mathrm{~m}$. The intensity of the natural radioactivity determined from the neutron-neutron logging increases very 


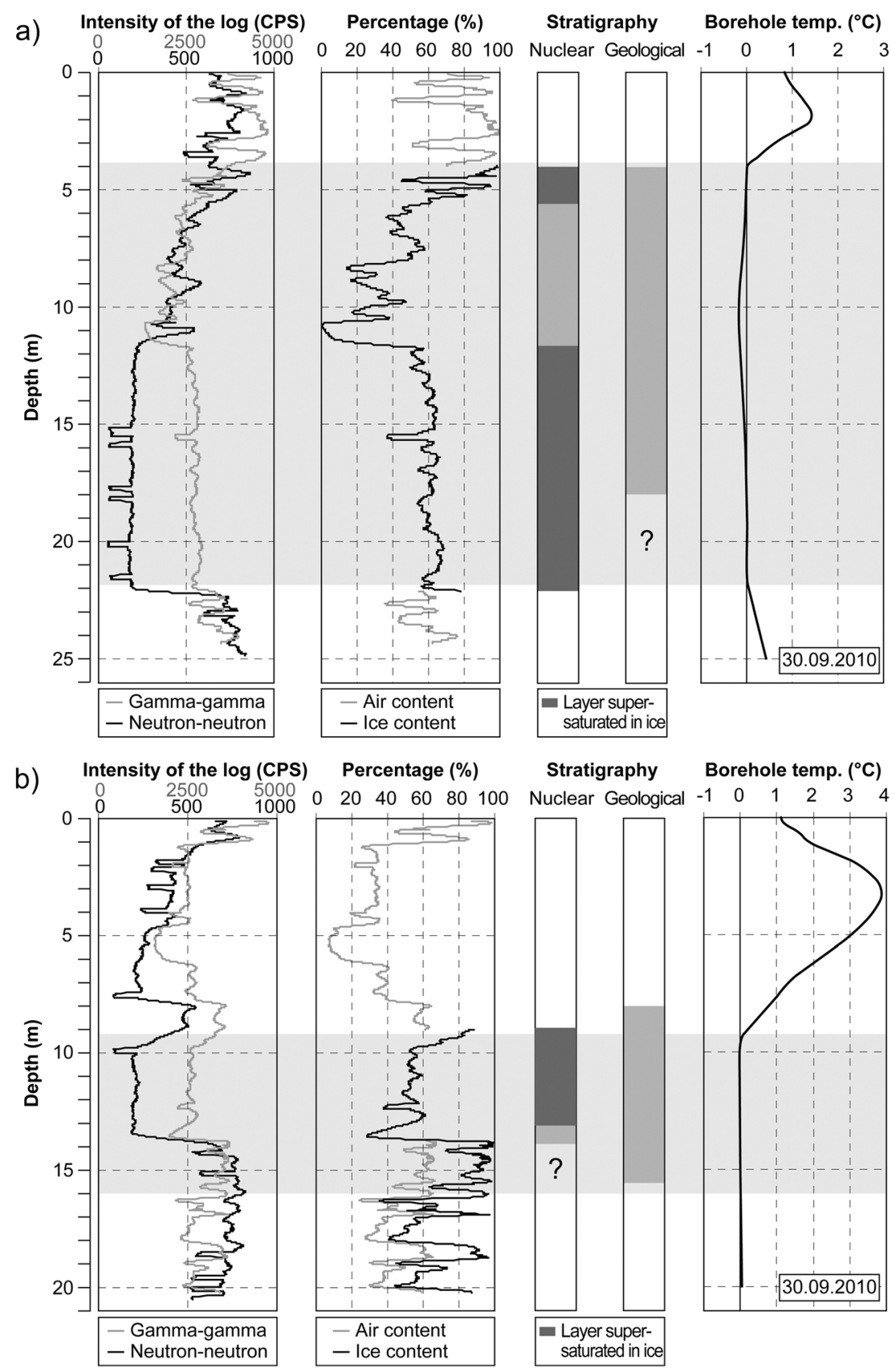

Figure 8 Quantification of ice content and nuclear stratigraphy of well logging at Petit Mont Rouge. Grey-shaded sections indicate a frozen ground according to borehole temperature. Geological stratigraphy was determined during drilling and by the use of a borehole camera (for details, see Scapozza et al., 2011a). (a) Borehole 1/2009. (b) Borehole 2/2009.

strongly below this layer, with values similar to those recorded in the first part of the active layer.

\section{Interpretation.}

The decrease in radioactivity recorded in the natural gamma-ray log may be related to the existence of permafrost that is supersaturated with ice, as indicated by the geoelectrical (resistivities $>200 \mathrm{k} \Omega \mathrm{m}$ ) and seismic refraction (velocities $>3000 \mathrm{~m} / \mathrm{s}$ ) prospecting carried out on the protalus rampart (Scapozza, 2013). On the other hand, the large increase in radioactivity in the active layer of Borehole $2 / 2009$ pointed to the voids in the talus slope being filled progressively by fine materials (decrease in air content). Considering the very high electrical resistivities $(>100$ $\mathrm{k} \Omega \mathrm{m})$ and the high seismic velocities $(>2000 \mathrm{~m} / \mathrm{s})$ measured by surface geophysical prospecting (Scapozza, 2013), the lack of natural gamma-rays between depths of 10 and $15 \mathrm{~m}$ indicates a probable supersaturation in ice. 
High intensities of the gamma-gamma log show a low density, which is also related to the high air content (50-90\%) related to the voids in the loose debris surface layer of Boreholes 1/2009 and 2/2009. The weak variations in the gamma-gamma intensity and the bulk density of $1.5-1.7 \mathrm{~g} / \mathrm{cm}^{3}$ recorded between depths of 11.5 and $22 \mathrm{~m}$ in Borehole 1/2009 indicate that this sector is probably marginally supersaturated, with an ice content between 50 and 65 per cent (Figure 8a).

The neutron-neutron log for Borehole 1/2009 confirms the interpretation of the gamma-gamma log: a decrease in air content between the surface and a depth of $11 \mathrm{~m}$ and high ice content between depths of 11.1 and $22.2 \mathrm{~m}$. Low CPS values measured in Borehole 2/2009 indicate the occurrence of permafrost supersaturated with ice between depths of 10 and $13.5 \mathrm{~m}$. The neutron-neutron $\log$ shows that this part of the slope does not contain ice below this layer (Figure 8b). A reinterpretation of the intensity of the gamma-gamma log, in terms of air content (and not of ice content), shows values that are more coherent compared with the surface morphology and the borehole stratigraphy, determined from the visual inspection using a borehole camera and material expulsion.

The nuclear stratigraphy in the protalus rampart (Borehole 1/2009) shows that the table and the base of the ice-rock mixture correspond to the table and the base of the permafrost determined in the thermal profile (Figure 8a). Borehole logging in the lower part of the talus slope (Borehole $2 / 2009$ ) shows that there is a complex stratigraphy in the active layer, with a layer filled with fine materials (air content lower than 20\%) intercalated between two porous layers (Figure $8 b$ ). This could be an indication of a recent degradation of permafrost by a deepening of the active layer (which is $10 \mathrm{~m}$ deep), as evidenced by borehole temperatures (Scapozza, 2013). Fine materials were therefore not yet washed toward the permafrost table. The nuclear stratigraphy confirms the geological stratigraphy below a depth of $14 \mathrm{~m}$ and shows that the lower part of the frozen layer is characterised by dry permafrost.

\section{DISCUSSION}

\section{Nuclear Properties of Talus Slopes}

In the absence of outcrops and cores allowing a direct study of the geological structure of talus slopes, information obtained by well logging, as well as visual observations carried out using a borehole camera (see Scapozza et al., 2011a; Scapozza, 2013), allowed the ground structure to be characterised. It was also possible to estimate the air and ice contents in the two lowest boreholes of the three prospected talus slopes.

Nuclear logs confirm that free pore space decreases with depth at all three study sites because of the natural effect of vertical effective stress of rock debris and/or the increase in matrix, which fills the voids. A (very) porous surface layer exists under low stresses that can exhibit local arching and void formation above a layer of boulders and pebbles in a gravel, sandy or silty matrix (depending on the lithology of each site), and is typical both in natural and anthropogenic outcrops that can be observed in Alpine talus slopes (Haeberli et al., 2006; Lambiel and Pieracci, 2008; Pieracci et al., 2008; Scapozza, 2013). This decrease in air content is characterised, from a nuclear point of view, in the natural gamma-ray log by an increase in CPS, and in the gammagamma and neutron-neutron logs by a decrease in CPS.

Well-graded materials with boulders and fines behave differently on a steep slope than in horizontal layers, showing that the progressive filling of voids with depth is not homogeneous:

- The active layer is generally very porous below the ground surface (air content of 40-80\%) and is characterised by a decrease in air content with depth. As the permafrost table constitutes a relatively impermeable layer, the finergrained soil particles accumulate at the base of the active layer. This also indicates that accumulation in voids at the base of the active layer is more likely than the particles being washed through the voids by water flow from rainfall, snow melting or water thawed from seasonal ice.

- The air content seems to decrease gradually in the permafrost body, from the permafrost table to the base of the perennially frozen layer (where it was reached).

- Where the boreholes cross the permafrost base (Les Lapires and Petit Mont Rouge talus slopes), the air content increases strongly below the permafrost body, as evidenced, for example, also in the Murtél-Corvatsch rock glacier in a talik below the permafrost (Springman et al., 2012). Data are available to a depth of $40 \mathrm{~m}$ at the Les Lapires site, where the air content decreases again, showing that the voids have been filled by fine deposits in the deeper part of the talus, which, at this site, has aggraded above a few metres of glacial deposits.

Well logging is coherent with the geophysical data with respect to the ground ice content and estimates proposed by the surface morphology (Scapozza et al., 2011a; Scapozza, 2013). When the surface morphology is rectilinear, the talus slope is often partially saturated with ice (Les Attelas, $<40 \%$; Les Lapires, 20-40\%) or, at most, saturated with ice (layer with a maximal ice content of 50-60 per cent at Les Lapires and in Borehole 2/2009 at the Petit Mont Rouge talus slope). Where a permafrost creeping landform exists (the Petit Mont Rouge protalus rampart), on the other hand, well logging indicates a supersaturation of the ice in the voids of the ground (ice content of about $60 \%$ in Borehole 1/2009). Thus, the well logging carried out in this study confirms that the ice content of a talus slope is lower than that in a rock glacier, where the ice content can reach, according to well logging data, 70-90 per cent (Barsch et al., 1979; Vonder Mühll and Holub, 1992; Arenson et al., 2002; Haeberli et al., 2006).

\section{Contribution of Well Logging}

Well logging allowed fundamental information about the geological and nuclear structure of the permafrost to be 
obtained in the absence of undisturbed cores being extracted from the boreholes. It was possible to obtain continuous information about the variations in density and the apparent porosity in a talus slope using the three nuclear logs.

The calibration of gamma-gamma and neutron-neutron logs permitted the quantification of some parameters, such as the ice and air contents of permafrost, which then can be integrated in four-phase models (4PM) obtained from the joint inversion of geoelectrical and seismic data (Hauck et al., 2008, 2011). The 4 PM approach is normally based on an estimate of porosity (Hauck and Kneisel, 2008; Hilbich, 2009), which leads to the development of a model that is strictly dependent on porosity (a so-called porosity-dependent model), and where the porosity pre-determines the space available for ice, water and air. A main problem of deriving a $4 \mathrm{PM}$ based on geoelectrical and seismic data is the estimate of porosity, which has a significant degree of uncertainty in terms of spatial variability. This can be resolved by integrating well logging data, as shown by this study. The ice content may be calculated from the gamma-gamma log and can be subtracted from the apparent porosity, which will be calculated from the neutron-neutron $\log$, and so it should be possible to quantify air/water content, which allows an almost complete evaluation of the volumetric fractions quantified by the 4PM. In addition to this, the air content calculated from the gamma-gamma log allows a verification to be made of the air content determined by the 4PM in unfrozen layers or frozen layers without ice. This contribution of well logging in the $4 \mathrm{PM}$ will be shown in a separate publication.

The integration of well logging in the $4 \mathrm{PM}$ carried out in talus slopes may be particularly suitable, because: (1) porosity does not decrease linearly in a talus slope with depth, as postulated in the $4 \mathrm{PM}$, but can vary strongly as a function of the layers composing the subsurface; and (2) contrary to rock glaciers, which are normally supersaturated with ice, the ice content in a talus slope can be extremely variable from one layer to another.

From a methodological point of view, the natural gammaray log provides extremely valuable information, in particular in crystalline rocks, because the natural radioactivity of ice and air is zero. This log then allows the evaluation of variations in the rock content (debris and interstitial matrix) as a function of depth. It is less efficient for detecting icerich layers, because a discrimination between air and ice (both characterised by low CPS values) can be performed by the natural gamma-ray log only where the talus slope is supersaturated with ice (e.g. in Borehole 1/2009 on the Petit Mont Rouge site). The contribution of this $\log$ is to provide data for checking the results recorded by the other two nuclear logs, and to give information about the rock content (then on the air content).

The gamma-gamma log allows significant information to be obtained about the subsurface. As this log is sensitive to variations in bulk density, it allows the calculation of the ice content in frozen layers and the air content in unfrozen layers. It is, however, necessary to have temperature data from the ground in order to interpret the data recorded by this logging in permafrost terrain in more detail. The application of a neutron-neutron $\log$ is not so conventional in well logging. This log was tested alongside a gammagamma log. The neutron-neutron $\log$ is very sensitive to variations in porosity, which has allowed the calculation of the air content inside the frozen layer. The approach based on the joint application of gamma-gamma and neutron-neutron logs is justified on account of the fact that the trend in the apparent porosity calculated from the neutron-neutron log was confirmed by the ice content calculated from the gamma-gamma log. The two logs provide mirror images determined by two independent methods, which allow the recorded data to be cross-checked for consistency.

\section{CONCLUSIONS}

Based on nuclear well logging carried out in six boreholes in Alpine periglacial talus slopes, the following conclusions are drawn about the structure of these landforms:

1. Increasing in-situ stresses that cause compression of the rock debris and the existence of a fine matrix filling the voids are deduced by a general decrease in the air content with depth.

2. The progressive filling of voids with depth is not homogeneous. The active layer is generally very porous at the surface (40-80\%) and shows a decrease in air content in proportion to the proximity of the permafrost table. The permafrost body generally shows a progressive decrease in air content with depth, whereas air content can strongly increase below the permafrost base (e.g. Les Lapires and Petit Mont Rouge).

3. Well logging in Borehole 2/2009 at the Petit Mont Rouge site highlights the existence, in the active layer, of very porous layers intercalated by a layer filled with fine materials indicating a probable recent degradation of permafrost.

4. Ice content variations show that talus slopes are frequently partially saturated with ice or, at most, saturated with ice (ice content in ice-rich layers between 20 and $50 \%)$.

5. A supersaturation in ice (ice content of about $60 \%$ ) is observed only in a creeping permafrost landform (the Petit Mont Rouge protalus rampart), confirming a direct relationship between ground ice content and surface morphology of the landforms.

6. Air/water content in unfrozen layers and ice content in frozen layers determined from the density log, and ice content from the porosity log, allows three-phase models (rock, ice and air/water) of the subsurface to be obtained.

7. Complementary information about the progressive infilling of the voids with depth and the occurrence of ice-rich layers is provided by the three measured logs.

8. The joint application of gamma-gamma and neutronneutron $\log$ s provides a mirror image of ice content 
and the apparent porosity, highlighting a similar trend in these two parameters.

Based on these considerations, the joint application of the three nuclear logs must be encouraged in all drilling projects in permafrost, as recommended by Vonder Mühll (1996). The application of natural gamma-ray, gamma-gamma and neutron-neutron logs must be considered in all cases as being a minimal well logging approach because of the complementarity for the determination of ice, rock and air/water contents.

\section{ACKNOWLEDGEMENTS}

This work was funded by the Swiss National Science Foundation (project number 200021-119854). We would like to thank all those who helped in the fieldwork, in particular Nicola Deluigi. We give special thanks to the Editor, Dr Julian Murton, the Associate Editor, Prof. Sarah Springman, and to the two anonymous reviewers for their useful feedback, as well as to Lisa Martinenghi for proofreading the English.

\section{REFERENCES}

Arenson LU. 2002. Unstable alpine permafrost: a potentially important natural hazard - Variations of geotechnical behaviour with time and temperature. $\mathrm{PhD}$ thesis, ETH Zurich (Diss. ETH No. 14801). http://ecollection.ethbib.ethz.ch/view/eth:25904 [4 November 2014].

Arenson LU, Springman S. 2005. Triaxial constant stress and constant strain rate tests on ice-rich permafrost samples. Canadian Geotechnical Journal 42: 412-430. DOI: 10.1139/t04-111

Arenson LU, Hoelzle M, Springman S. 2002. Borehole deformation measurements and internal structures of some rock glaciers in Switzerland. Permafrost and Periglacial Processes 13: 117-135. DOI: 10.1002/ ppp.414

Baron L, Chapellier D. 2000. Calibration of environmental nuclear tools based on core sample analysis: root mean square and neural network approaches. European Journal of Environmental and Engineering Geophysics 4: 129-149.

Barsch D. 1996. Rockglaciers. Indicators for the Present and Former Geoecology in High Mountain Environments. Springer: Berlin/Heidelberg.

Barsch D, Fierz H, Haeberli W. 1979. Shallow core drilling and bore-hole measurements in the permafrost of an active rock glacier near the Grubengletscher, Wallis, Switzerland. Arctic and Alpine Research 11: 215-228.

Chapellier D 1987. Diagraphies appliquées à l'hydrogéologie. Lavoisier Technique et Documentation: Paris.

Chapellier D, Baron L, Monnet R. 2000. Slim hole logging in shallow boreholes. Annals of Geophysics 43: 1119-1130. DOI: 10. 4401/ag-3690

Dakhnov VN 1959. Geophysical well logging (translated by G.V. Keller). Quarterly of the Colorado School of Mines 57(1962): 1-445.

Delaloye R, Lambiel C 2005. Evidence of winter ascending air circulation throughout talus slopes and rock glaciers situated in the lower belt of alpine discontinuous permafrost (Swiss Alps). Norsk Geografisk Tidsskrift 59: 194-203. DOI: 10.1080/ 00291950510020673

Ferrians OJ, Hobson GD. 1973. Mapping and predicting permafrost in North America: a review, 1963-1973. In Proceedings of the $2^{\text {nd }}$ International Conference on Permafrost, Péwé TL, MacKay JR (eds). National Academy of Sciences: Washington D.C., Yakutsk, USSR, 13-28 July 1973, North American Contributions; 479-498.

Francou B, Hétu B. 1989. Eboulis et autres formations de pente hétérométriques: contribution à une terminologie géomorphologique. Notes et Comptes-rendus du groupe de travail "Régionalisation du Périglaciaire" 14: 11-69.

Guyod H, Shane LE. 1969. Geophysical well logging, Volume I. Hubert Guyod: Houston, TX.

Haeberli W, Hallet W, Arenson L, Elconin R, Humlum O, Kääb A, Kaufmann V, Ladanyi B, Matsuoka N, Springmann S, Mühll DV. 2006. Permafrost creep and rock glacier dynamics. Permafrost and Periglacial Processes 17: 189-214. DOI: 10.1002/ppp.561

Harris C, Davies MC, Etzelmüller B. 2001. The assessment of potential geotechnical hazards associated with mountain permafrost in a warming global climate. Permafrost and Periglacial Processes 12: 145-156. DOI: 10.1002/ppp.376

Hauck C, Kneisel C. 2008. Quantifying the ice content in low-altitude scree slopes using geophysical methods. In Applied Geophysics in Periglacial Environments, Hauck C, Kneisel C (eds). Cambridge University Press: Cambridge; 153-164.

Hauck C, Bach M, Hilbich C 2008. A fourphase model to quantify subsurface ice and water content in permafrost regions based on geophysical data sets. In Proceedings of the $9^{\text {th }}$ International Conference on Permafrost, Kane DL, Hinkel KM (eds). Institute of Northern Engineering, University of Alaska Fairbanks: Fairbanks, Alaska, 29 June-3 July 2008; 675-680.

Hauck C, Böttcher M, Maurer HR. 2011. A new model for estimating subsurface ice content based on combined electrical and seismic data sets. The Cryosphere 5: 453-468. DOI: 10.5194/tc-5-453-2011

Hilbich C. 2009. Geophysical monitoring systems to assess and quantify ground ice evolution in mountain permafrost. $\mathrm{PhD}$ thesis, Friedrich Schiller University of Jena. http://www.db-thueringen.de/servlets/DocumentServlet?id=13905 [4 November 2014].

Hilchie DW. 1978. Applied openhole log interpretation. Douglas W. Hilchie Inc.: Golden, CO.

Keys WS, MacCary LM. 1971. Application of borehole geophysics to water-resources investigations. US Government Printing Office: Washington, DC.

Lambiel C, Pieracci K 2008. Permafrost distribution in talus slopes located within the alpine periglacial belt, Swiss Alps. Permafrost and Periglacial Processes 19: 293-304. DOI: 10.1002/ppp.624

Lütschg M, Stöckli V, Lehning M, Haeberli W, Ammann W 2004. Temperatures in two boreholes at Flüela Pass, Eastern Swiss Alps: the effect of snow redistribution on permafrost distribution patterns in high mountain areas. Permafrost and Periglacial Processes 15: 283-297. DOI: 10.1002/ppp.50

Mari J-L, Arens G, Gaudiani P, Chapellier D 1999. Geophysics of reservoir and civil engineering. Editions Technip: Paris.

Maurer H, Springman SM, Arenson LU, Musil M, Vonder Mühll D 2003. Characterisation of potentially unstable mountain permafrost - A multidisciplinary approach. In Proceedings of the $8^{\text {th }}$ International Conference on Permafrost, Philips M, Springman SM, Arenson L (eds). Balkema: Lisse, Zurich, Switzerland, 21-25 July 2003; 741-746.

Musil M, Maurer H, Holliger K, Green AG 2006. Internal structure of an alpine rock glacier based on crosshole georadar traveltimes and amplitudes. Geophysical Prospecting 54: 273-285. DOI: 10.1111/j.1365-2478. 2006.00534.x

Osterkamp TE, Payne MW 1981. Estimates of permafrost thickness from well logs in Northern Alaska. Cold Regions Science 
and Technology 5: 13-27. DOI: 10.1016 0165-232X(81)90037-9

Otto JC, Sass O 2006. Comparing geophysical methods for talus slope investigations in the Turtmann valley (Swiss Alps). Geomorphology 76: 257-272. DOI: 10.1016/j. geomorph.2005.11.008

Petersen JK, Kawasaki K, Osterkamp TE, Scott JH 1985. Nuclear well logging in permafrost. AAPG Bulletin, American Association of Petroleum Geologists 69: 674-675.

Phillips M, Zenklusen ME, Kern-Lütschg M, Lehning M 2009. Rapid degradation of ground ice in a ventilated talus slope: Flüela Pass, Swiss Alps. Permafrost and Periglacial Processes 20: 1-14. DOI: 10.1002/ppp.638

Pieracci K, Lambiel C, Reynard E 2008. Distribution et caractéristiques du pergélisol dans les éboulis de haute altitude (Hautes Alpes Calcaires, VS, Suisse). Géomorphologie: relief, processus, environnement 2/2008 87-97. DOI: 10.4000/geomorphologie.6143

Pirson S. 1963. Handbook of well log analysis. Prentice-Hall: Englewood Cliffs, NJ.

Sass O, Krautblatter M. 2007. Debris flowdominated and rockfall-dominated talus slopes: genetic models derived from GPR measurements. Geomorphology 86: 176192. DOI: 10.1016/j.geomorph.2006.08.012

Scapozza C. 2013. Stratigraphie, morphodynamique, paléoenvironnements des terrains sédimentaires meubles à forte déclivité du domaine périglaciaire alpin. $\mathrm{PhD}$ thesis, University of Lausanne.
Géovisions 40: Lausanne. http://www.unil. ch/igul/page96426.html [4 November 2014].

Scapozza C, Laigre L. 2014. The contribution of electrical resistivity tomography (ERT) in alpine dynamics geomorphology: case studies from the Swiss Alps. Géomorphologie: relief, processus, environnement 1/2014: 27-42. DOI: 10. 4000/geomorphologie.10474

Scapozza C, Lambiel C, Baron L, Marescot L, Reynard E 2011a. Internal structure and permafrost distribution in two alpine periglacial talus slopes, Valais, Swiss Alps. Geomorphology 132: 208-221. DOI: 10 1016/j.geomorph.2011.05.010

Scapozza C, Lambiel C, Gex P, Reynard E 2011b. Prospection géophysique multiméthodes du pergélisol alpin dans le sud des Alpes suisses. Géomorphologie: relief, processus, environnement 1/2011: 15-32. DOI: 10.4000/geomorphologie. 8765

Scapozza C, Lambiel C, Bozzini C, Mari S, Conedera M. 2014. Assessing the rock glacier kinematics on three different timescales: a case study from the southern Swiss Alps. Earth Surface Processes and Landforms. DOI: 10.1002/esp.3599

Scott JH, Petersen JK, Osterkamp TE, Kawasaki K. 1986. Interpretation of geophysical well logs in permafrost. Final report. US Department of Energy, Office of Fossil Energy: Morgantown, WV.
Scott WJ, Sellman PV, Hunter JA. 1978 Geophysics in the study of permafrost. In Proceedings of the $3^{\text {rd }}$ International Conference on Permafrost, Crawford CB (ed). National Research Council of Canada: Ottawa, Edmonton, Alberta, Canada, 10-13 July 1978, 2; 93-115.

Springman SM, Arenson LU, Yamamoto Y, Maurer H, Kos A, Buchli T, Derungs G. 2012. Multidisciplinary investigations on three rock glaciers in the Swiss Alps: legacies and future perspectives. Geographiska Annaler: Series A, Physical Geography 94: 215-243. DOI: 10.1111/j.1468-0459.2012. 00464.x

Steijn van H, Boelhouwers J., Harris S., Hétu B. 2002. Recent research on the nature, origin and climatic relations of blocky and stratified slope deposits. Progress in Physical Geography 26: 551-575. DOI: 10. 1191/0309133302pp352ra

Vonder Mühll D. 1996. Drilling in Alpine permafrost. Norsk Geografisk Tidsskrift 50: 17-24. DOI: 10.1080/00291959608552348

Vonder Mühll D, Holub P 1992. Borehole logging in alpine permafrost, Upper Engadin, Swiss Alps. Permafrost and Periglacial Processes 3: 125-132. DOI: 10.1002/ppp. 3430030209

Vonder Mühll D, Hauck C, Lehmann F. 2000. Verification of geophysical models in $\mathrm{Al}-$ pine permafrost using borehole information. Journal of Glaciology 31: 300-306. DOI: $10.3189 / 172756400781820057$ 